・招待戡演・

\title{
ON THE SUPPLY OF FOOD TO FARM HOUSEHOLDS IN THE FEDERAL REPUBLIC OF GERMANY
}

\author{
By \\ Priv. -Dozent Dr. Willi WIRTHS \\ Max-Plank-Institute fiir Ernährungsphysiologie, Dortmund, Germany
}

The following data are based on nutrition surveys of small farms in Western Germany. Almost $90 \%$ of Western German farms are smaller than 40 acre or 16 ha LN-farming area. None of the surveyed familied had more. It can be assumed that the unsatisfactory economic, social, and cultural situation of these families affects their nutrition accordingly.

Among all farm types, families with small farm in areas have the greatest difficulties to obtain sufficient nutrition. This is mainly due to the manner of food consumption-larger farms have a great production of their own and also buy more foodstuffs. In many cases, we find a surplus of nutrients among them.

Our findings in small fams are not as depres-sing as similar reports by Medici of Italy, who

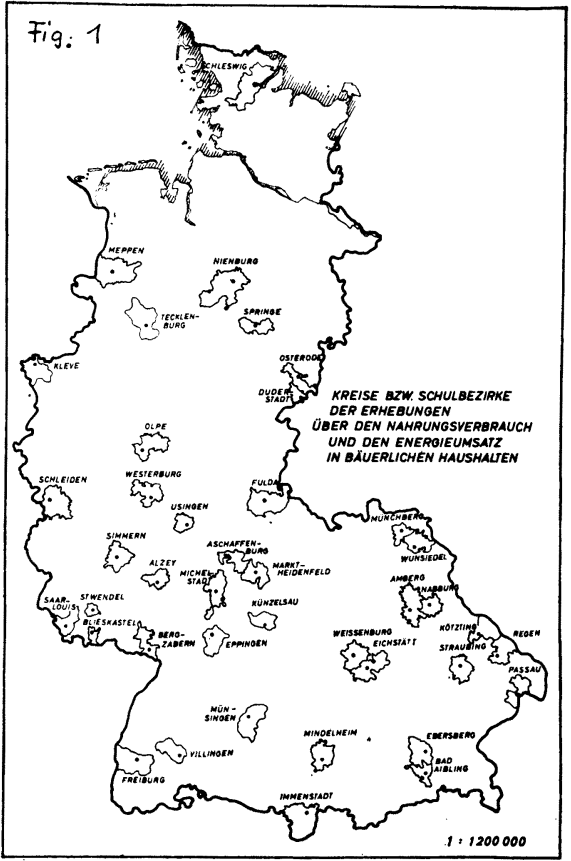
speaks of malnutrition as one of the most impressive pathological signs of small farms. But with $\mathrm{s}$ ome reservations we can agree with that statement. Moreover, the Italian agricultural economist emphasizes the frequency of typical deficiency diseases, such as Beri beri, Pellagra, and Scurvy which we have not been able to find in any of our 400 families surveyed.

[Slide 1] shows the regions, there are 41 different rural countries of the Federal Republic of Germany, where nutritional status has been determined. The surveys cover periods of 30 days during the vegetation period. By that we wanted to find out how energy output caused by heavy physical activity compares with energy intake through foodstuff consumption.

In earlier experiments, we were able to get results concerning physiology of agricultural, forestry, and household work by measuring energy metabolism and pulse rate.

In order to evaluate the respective work-physiological and nutritional data, we had to arrange 
the subjects systematically according to sex, age, body weight, body height, and physical activity or predominating work. Acordingly, we formed groups by age and physical activity. For the calculation of the nutrient requirements, we based ourselves on the recommendations of the German Nutrition Society as well as on basal metabolism calories. These tables neither give the minimum requirements nor optimum food supplies. They merely recommended desirable food consumption. It is general experience that healthy persons who consume the recommended amounts of food maintain a good nutri- tional status and do not develop deficiency signs.

The daily calorie requirement is demonstrated in [slide 2.] The factor 1,1344 is calculated of 6 $\%$ of the whole calorie consumption for the specific dynamic action and likewise $6 \%$ for the diminished resorption; $\mathrm{BM}=$ Basal metabolism, $\mathrm{FM}=$ Freetime metabolism and $\mathrm{WM}=$ Work metabolism. Calculated of the food intake indicates whether the requirements for essential nutrients are correct. Our data refer to the main nutrients, such as protein (including animal protein), fat, carbohydrates, the minerals calcium, phosphorus, and iron, as well as vitamins $A, B_{1}, B_{2}$, niacin (PP), and C. Mean daily intakes per head shows [slide 3] calories 3420, protein $92 \mathrm{gm}$., $53 \mathrm{gm}$. of which of animal origin, fat $144 \mathrm{gm}$., carbohydrates $405 \mathrm{gm}$., calcium $1.1 \mathrm{gm}$., phosphorus $1,9 \mathrm{gm}$., iron $18 \mathrm{mg}$., axerophthol $5530 \mathrm{I}$. U., thiamin $1.9 \mathrm{mg}$., riboflavine $2.1 \mathrm{mg}$., niacin $18 \mathrm{mg}$, and ascorbic acid $92 \mathrm{mg}$.

Fig. 2

\begin{tabular}{rl|}
\hline DAILY CALORIE REQUIREMNT \\
$=\frac{1.1344(\mathrm{BM}+\mathrm{FM}+\mathrm{WM})}{\mathrm{BM}}=$ BASAL METABOLISM \\
$\mathrm{FM}=$ FREETIME METABOLISM \\
WM $=$ WORK METABOLISM \\
\hline FORMULA FOR CALCULATE DAILY
\end{tabular}

Fig. 3

\begin{tabular}{|c|c|c|c|c|}
\hline & & & $\begin{array}{l}\text { Nährstoffgehalt } \\
\text { nach Verbrauch }\end{array}$ & $\begin{array}{l}\text { Nährstoffaufnahme } \\
\text { nach Verzehr }\end{array}$ \\
\hline \multicolumn{3}{|l|}{ Kalorien } & 3700 & 3420 \\
\hline \multicolumn{2}{|c|}{ Eiweiss } & (g) & 101 & 92 \\
\hline \multirow{2}{*}{\multicolumn{2}{|c|}{$\begin{array}{l}\text { davon tierisch } \\
\text { Fett }\end{array}$}} & (g) & 57 & 53 \\
\hline & & (g) & 153 & 144 \\
\hline \multicolumn{2}{|c|}{ Kohlenhydrate } & (g) & 445 & 405 \\
\hline \multicolumn{2}{|l|}{ Calcium } & (g) & 1.2 & 1.1 \\
\hline \multirow{2}{*}{\multicolumn{2}{|c|}{ Phosphor }} & (g) & 2.0 & 1.9 \\
\hline \multirow{2}{*}{$\begin{array}{l}\text { Eisen } \\
\text { Vitamin }\end{array}$} & & (mg) & 20 & 18 \\
\hline & A & (I.E.) & 5930 & 5530 \\
\hline \multicolumn{2}{|l|}{ Vitamin } & (mg) & 2.1 & 1.9 \\
\hline Vitamin & $\mathrm{B}_{2}$ & (mg) & 2.3 & 2.1 \\
\hline \multirow{2}{*}{$\begin{array}{l}\text { Vitamin } \\
\text { Vitamin }\end{array}$} & Niacin & (mg) & 20 & 18 \\
\hline & C & (mg) & 105 & 92 \\
\hline & & $\begin{array}{l}\text { Nähr } \\
\text { Mit }\end{array}$ & $\begin{array}{l}\text { fautfnahme } \\
\text { aller Haushalte }\end{array}$ & \\
\hline
\end{tabular}

During the survey, every family was personally visited in order to assess individual characteristics necessary for grouping of the subjects and exact calculation of food consumption.

In rural families, there is furthermore the problem of how to separate foodstuffs consumed by humans and by animals. In cases where animals regularly received leftovers of human foodstuffs, this was considered in the calculation. In cases where leftover foodstaffs were fed only irregularly and also not always to the same animals, we had to rely on personal judgment. Beyond that, $10 \%$ 
(16)

of the calculated values were deducted for wastage.

The evaluation of the data showed great differences, as demonstrated in [slide 4.] The highest caloric intake was found in the district of Freiburg, that is to say 4,170 calories. Households in the district of Künzelsau are approximately 1,500 calories lower. The protein calories are between 9.8 and $12.3 \%$, in most cases between 11 and 12\%. The fat caloriles are between 32 and 52\%.

These values do not indicate the requirements covered by individual families. The total protein

Fig. 4

Nächster und niedrigster

Nährstoffverbrauch

Kopf / Tag

\begin{tabular}{|c|c|c|c|c|c|}
\hline \multirow{2}{*}{\multicolumn{2}{|c|}{ Nährstoffe }} & \multirow{2}{*}{\multicolumn{2}{|c|}{ 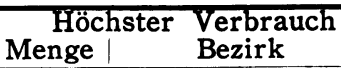 }} & \multicolumn{2}{|c|}{ Niedrigster Verbrauch } \\
\hline & & & & & Bezirk \\
\hline Eiweis insges & g & 109 & Meppen & 74 & Bad Aibling \\
\hline tiersch & g & 60 & Freiburg & 41 & Villingen \\
\hline Eett & g & 230 & Freiburg & 104 & Künzelsau \\
\hline Kohlenhydrate & & 490 & Schleiden & 330 & Osterode \\
\hline Calorien & kcal & 4170 & Freiburg & 2710 & Künzelsau \\
\hline Calcium & $g$ & 1,5 & Olpe & 0.8 & Alzey \\
\hline Phosphor & g & 2,3 & Weissenburg & 1.5 & Künzelsau \\
\hline Eisen & $\mathrm{mg}$ & 21 & Springe & 14 & Regen \\
\hline Vitamin & IE & 8220 & Alzey & 3380 & Künzelsau \\
\hline Vitamin & $\mathrm{mg}$ & 2.7 & Meppen & 1.4 & Künzelsau \\
\hline Vitamin & $\mathrm{mg}$ & 2.6 & Mindelheim & 1.6 & Villingen \\
\hline Vitamin Niacin & $\mathrm{mg}$ & 23 & Schleiden & 12 & Regen \\
\hline Vitamin C & $\mathrm{mg}$ & 185 & Schleiden & 40 & Künzelsau \\
\hline
\end{tabular}

Fig. 5

Höchster und niedrigster

Nahrungsmittelverbrauch

g / Kopf/ Tag

\begin{tabular}{|c|c|c|c|c|}
\hline \multirow[t]{2}{*}{ Nahrungsmittel } & \multicolumn{2}{|c|}{ Höchster Verbrauch } & \multicolumn{2}{|c|}{ Niedrigster Verbrauch } \\
\hline & Menge & Bezirk & Menge & Bezirk \\
\hline Getreideerzeugnisse (1 & $\begin{array}{l}445 \\
816\end{array}$ & $\begin{array}{l}\text { Passau } \\
\text { Schleiden }\end{array}$ & $\begin{array}{r}222 \\
90\end{array}$ & $\begin{array}{l}\text { Tecklenburg } \\
\text { Bad Aibling }\end{array}$ \\
\hline Zucker & 106 & Straubing & 41 & Aschaffenburg \\
\hline Gemüse & 264 & Ebersberg & 84 & Künzelsau \\
\hline Obst & 379 & Ebersberg & 69 & Marktheidenfeld \\
\hline Fleisch & 218 & Eichstätt & 60 & Kötzting \\
\hline Rindfleisch & 59 & Freiburg & 5 & Kötzting \\
\hline Schweinefleisch & 176 & Amberg & 32 & Kötzting \\
\hline Milch & 1045 & Olpe & 294 & Alzey \\
\hline Käse & 42 & Wunsiedel & 4 & Ebersberg \\
\hline Eier, Stück & 1.3 & Münsingen & 0.3 & Meppen \\
\hline Nahrungsfette & 152 & Freiburg & 45 & Künzelsau \\
\hline Butter & 69 & Olpe & 11 & Marktheidenfeld \\
\hline Margarine 3 & 41 & Freiburg & 1 & Regen \\
\hline Fisch & 27 & Springe & - & $\begin{array}{l}\text { Marktheidenfeld } \\
\text { Amberg }\end{array}$ \\
\hline 1) $\mathrm{Meh}$ & & & & \\
\hline 2) Reinfe & & & & \\
\hline Produkt & & & & \\
\hline
\end{tabular}

Von 360 bäuerlichen Haushalten

Iiegen unter $80 \mathrm{v}$. H. der

wünschenswerten Höhe

Fig. 6

der Nährstoffzufuhr

bei :

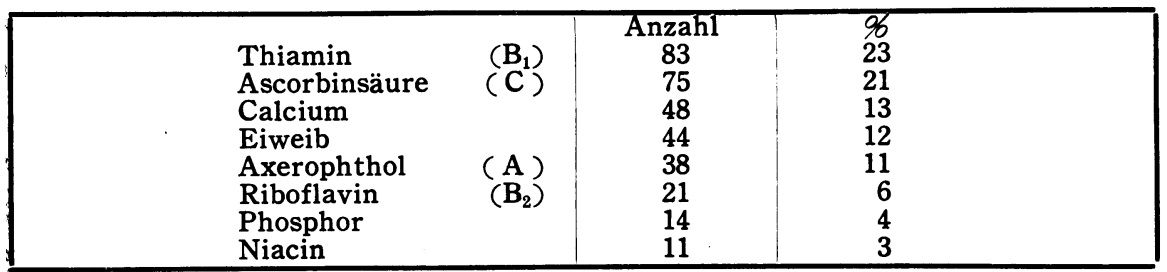


supply seems inadequate in many cases, as does also in some cases the supply of animal protein.. Fat intake, on the other hand, frequently exceeds the desirable amount. Among the minerals, the majority of the deficiencies are found with calcium. More than $20 \%$ of all families do not reach the recommended 1 gram per adult, per day. This seems surprising, since self-produced foodstuffs such as milk and cheese, and in addition several plant products are rich in calcium. These products are apparently not eaten in an amount adequate for an agricultural household living on mixed food; not whereas the requirements of phosphorous and iron are covered in nearly all households.

[Slide 5] shows the highest and the lowest consumption of important foodstuffs as averaged in the different counties in Passau; for instance, twice the amount of cereals is consumed as in Tecklenburg in Westfalia. The consumption of potatoes in Bad Aibling is only $1 / 9$ of the one in Schleiden. In Straubing, the amount of sugarconsumed is 2 and a half times as high as in Aschaffenburg. In Ebersberg, the consumption of vegetables is 3times as high as in Künzelsau, and for it consumption is 5 times as high as in Marktheidenfeld. The highest amount of meat is consumed in the district of Eichstätt, the lowest amount in the economically badly situated district of Kötzting. The households in Olpe shows the highest, the wine-growing farmers in Alzey the lowest intake of milk. The consumption of fat in Ereiburg is more than 3 times as high as in Künzelsau. In Freiburg, we find the highest intake in margarine, whereas almost no margarine is consumed in Regen. Fish consumption is highest in Springe, but almost no fish is consumed by the families in Marktheidenfeld and Amberg.

Nutrients supply is shown in [slide 6] from family to family. We found an insufficient supply of thiamin, vitamin C, calcium, protein, vitamin A, riboflavine and phosphorus. In $23 \%$ of the households, the requirements of vitamin $B_{1}$, in $21 \%$ by vitamin $C$, in $13 \%$ by calcium, in $12 \%$ by protein, in $11 \%$ by vitamin $\mathrm{A}$, and so on are not covered. Many families almost never drink milk. Moreover, we find $6 \%$ uncovered requirements of riboflavin, $4 \%$ of phosphorus.

Main nutritious matters :

Protein: The desired amount of protein supply equals to $93 \mathrm{gm}$. per capita and day. On an average of all households it amounts to $92.1 \mathrm{gm} .=99 \%$. Inspite of this result, 44, or $12 \%$ of all the households show less than $80 \%$ attained. The smallest amount was attained by a household with $56 \%$ of the Nominal Consumption. But, 41 households have been by $20 \%$ and more in excess of the nominal consumption. The desired amount of animal protein (approximately $42 \mathrm{gm}$.) is by far exceeded and amounts to $53.1 \mathrm{gm}$., or nearly $127 \%$ of the nominal consumption. From this it can be concluded that the households cover their protein required in the first line from animal products.

For 18 households, the protein supply of which was less than $80 \%$ of nominal consumption, the revaluation was extended to the contents of essential amino acids. Beside a "minimum required", a desired intake termed, due to studies of ROSE and ROSE et al., as "definitely safe intake" is indicated. With this, it is meant the double amount of "minimum required" of all essential amino acids. All of said 18 households cover an amount exceeding the desired intake of valine, leucine, isoleucine, threonin, phenylalanine, lysin, tryptophane. But none of them was able to take in, with the food, the desired amount of methionine. Mothionine is always the limiting amino acid. However, the methionine requirement can be largely covered, i.e. up to $80 \%$, by cystine. Same with phenyl.alanine which can be substituted up to approximately $70 \%$ by tyrosine

The lowest intake amount to $2.8 \mathrm{gm}$. for valine; $4 \mathrm{gm}$. for leucin; $2.6 \mathrm{gm}$. for isoleucin; $1.9 \mathrm{gm}$. for threonine $1.0 \mathrm{gm}$. for methionine; $2.6 \mathrm{gm}$. for phenylalanine; $2.6 \mathrm{gm}$. for lysin; and $0.7 \mathrm{gm}$. for tryptophane. All aforementioned minima are found in a household, which so can be said to be the .one with the poorest supply of essential amino acids. 
Fat: When following the DGE recommendations, a desired fat intake amounting to $99 \mathrm{gm}$. should be calculated as an average for all households. However, the average consumption amounts to nealy $144 \mathrm{gm}$., that means, approximately $146 \%$ are actually covered. You can also conclude from the high portion of fat calories which amounts to approximately $40 \%$ of the total amount of calories, that the nominal intake is largely exceeded.

With most of the households it is more than $100 \%$ of Nominal consumption. Less than $10 \%$ of the households indicate less than $100 \%$ of nominal fat consumption. One of them covers just $61 \%$ of the nominal figure. Beside it, there are 5 more households which cover less than $80 \% .27$ households cover more than $200 \%$ of the desired fat intake.

Calcium: The overall average Ca-intake of the households amounts to $111 \%$. Below $100 \%$ of nominal consumption are 140 households, below $80 \% 48$ households. However, 52 households cover more than $150 \%$ of the desired intake.

Phosphorus: Phosphate intake amounts, on an average to $126 \%$ of nominal cosumption. Just for the working man, sufficient supply with phosphoric acids is of high importance. With fat reduction, with the citric acid cycle as well as with the phosphorilisation of the respiratory cycle, strong phosphoric acid combinations grow, the energy of which is used for muscle contraction and various synthesises. -14 households cover less than $80 \%$ of the desired intake. The poorest supply was. stated with two families; it amounted to $68 \%$. On the other side, 70 households cover more than $150 \%$ of the desired intake. The amount of phosphate required is mostly calculated according to the $\mathrm{Ca}$-intake. The DGE recommandations say, the ratio $\mathrm{Ca}: \mathrm{P}$ should be equal to between $1: 1$ and $1: 2$. The average found with our panel amounts to $1: 1.6$, with a dispersion of from $1: 1.2$ up to $1: 2.1$. In 1961, the ratio in the Federal Republic of Germany was as high as $1: 1.9$ according to the "indirect food consumption".

Iron: Since a small portion of the iron taken in with the food, is resorbed only, -LANG-, a high daily iron intake is generally recommended. For farm households, a daily per capita nominal consumption amounting to $12 \mathrm{mg}$. is given. The evaluation showed for our panel an average amounting to no less than $150 \%$ of such nominal consumption. 16 households cover less than $100 \%, 2$ households less than $80 \%$. The poorest figure was shown with a household which covered $65 \%$ only. On the other hand, 25 househoulds covered more than $200 \%$.

Axerophthol (vitamin A) : The different resorption of pure vitamin A particularly of carotene, gives rise to recommend for this nutritious matter an extra of some inportance too, to make matters sure. On an average, the nominal intake amounting to $4530 \mathrm{I}$.U. is exceeded by $1000 \mathrm{I}$. U. i.e. by 22 $\%$. The intake is scattering, with the individual households, from $39 \%$ up to $368 \%$ of the desired amount. 38 hoseholds cover less than $80 \%, 20$ households more than $200 \%$.

Thiamine (vitamin $\mathrm{B}_{1}$ ) : Thiamine supply is covered, with $1.9 \mathrm{mg}$. on an average, by approximately $100 \%$ (99.9). The average is satisfying. But a great deal of the households does not cover the nominal figure of $1.9 \mathrm{mg}$. This applies to 204 households. One of them covers no more than $48 \%$. 83 households cover less than $80 \%$. 18 households cover more than $150 \%$ of the nominal value. After another methods, as demonstrated in [slide 7] at first in relation to the nonfat-calorie supply, and then in mcg per nonfat-colorie supply, we find out, that every times the most families don't reach the satisfactory supply of thiamine. The insufficient supply is not a result of the method than of the consumption habits of foodstuffs.

Riboflavine (vitamin $B_{2}$ ) : The average riboflavine intake amounts to $123 \%$ of the nominal supply. However, a fourth part of all the households does not cover the nominal intake. A households covers just $49 \% 21$ households cover less than $80 \%$. Maximum intake amounts to $229 \%$. 
Niacin (nicotinamide) : Up

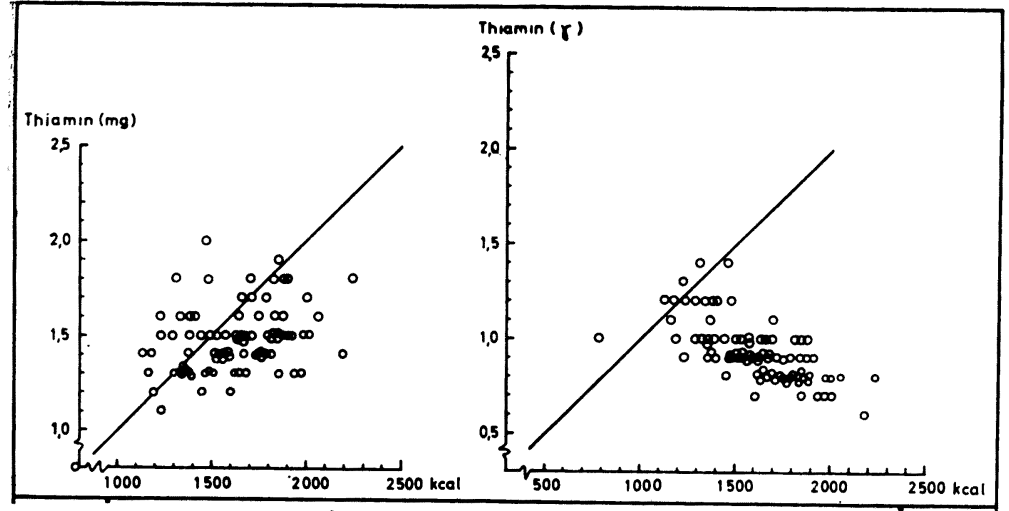

Fig. 7 und Nichtfettcalorien ( 83 Haushalte) in $\gamma$ je Nichtfettcalorie

to a certain extent, the aminocdi tryptophane is transformed, with man, into niacin, this way covering part of man's niacin requirement. This way, tryptophane can be considered as a provitamin of niacin.Therefore, when recommending any niacin intake, referenceis made to the tryptophane contents of the respective food. According to the studies of GOLDSMITH et al., as well as of HORWITT et al., on an average, 55 up to
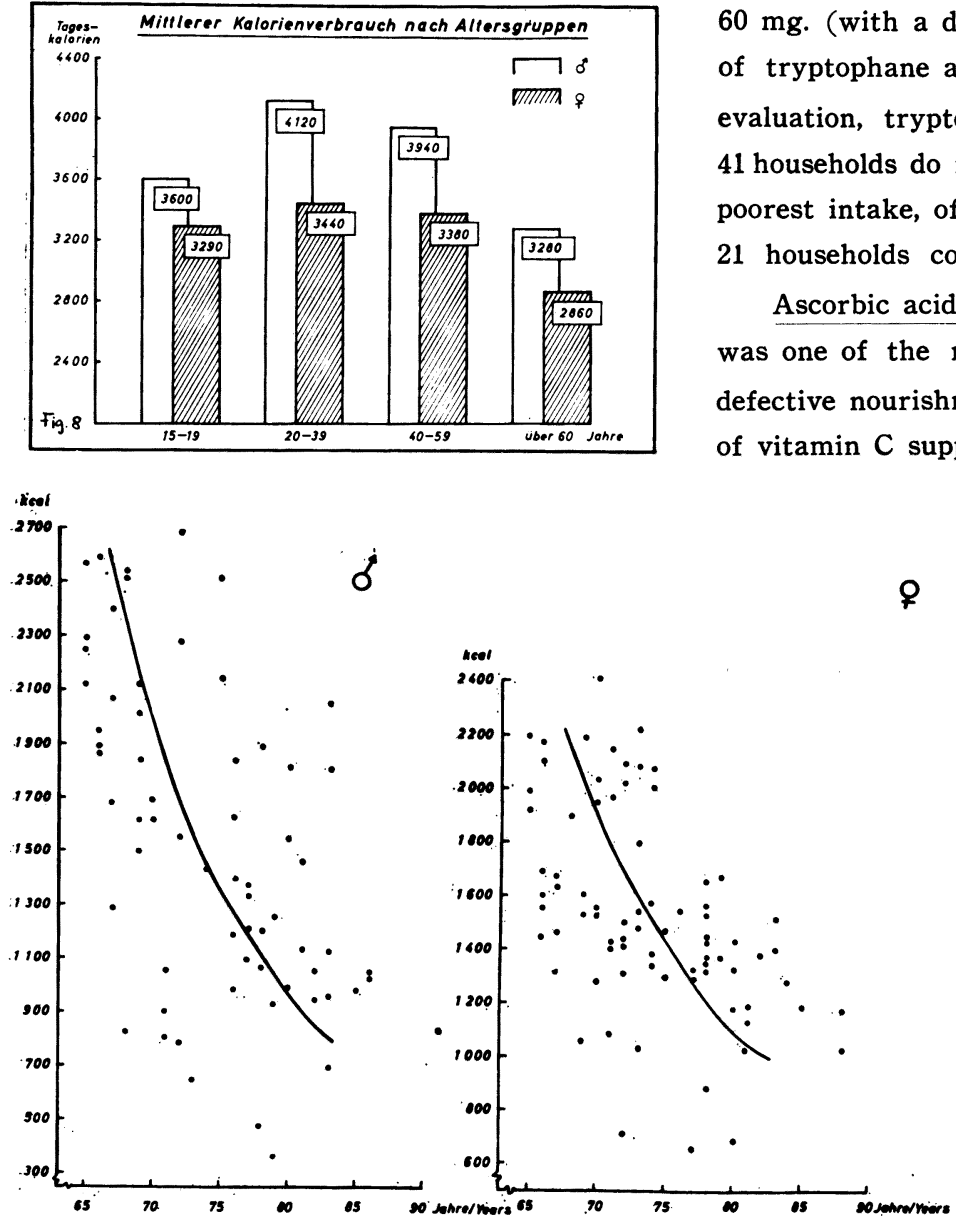

Fig. 9
ALTER UND ARBEITSUMSATZ AGE AND WORK METABOLISM
$60 \mathrm{mg}$. (with a dispersion of from $33 \mathrm{up}$ to $86 \mathrm{mg}$ ) of tryptophane are equal to $1 \mathrm{mg}$ Niacin. In our evaluation, tryptophane intake was not evaluated. 41 households do not cover the nominal intake. The poorest intake, of one household, amounts to $68 \%$. 21 households cover 200\% and more.

Ascorbic acid (vitamin C) : Previously, scurvy was one of the most wide-spread diseses due to defective nourishment. At the present time, lack of vitamin $\mathrm{C}$ supply results in gum inflammation, delayed healing of wounds and fractures of bone, reduced res istance to infections, quick fatigue,as well as other symptoms difficult to be objectivated.The DGE, and the Food and Nutrition Board, National Research Council, USA, recommend a daily dose of $75 \mathrm{mg}$ for the grown-up. For our panel the nominal intake amounts to 73 $\mathrm{mg}$. On an average, $92 \mathrm{mg}$ are attained, i. e. $126 \%$ of the desired intake. 75 households cover less than 80\%, 102 more than $150 \%$.

Furthermore, we looked for a correlation of calorie output and sex and age of the agricultural people. In [slide 8] is demonstrated the average 
calorie output by different groups of age of men and women. For both sexes, it shows the highest calorie output for the groups between $20-39$ years. followed by $40-56$ years. Over 60 years it shows a strong decreasing tendency. [Slide 9] demonstrates the development between age and work metabolism of the rural population in Germany. It shows, that sometimes deople of 75 years and elder must do hard work. Moreover, it shows, that the female sex in this age has nearly the same energy output than male. [Slide 10] shows, that elderly agricultural people with increasing body weight has much less working calories.

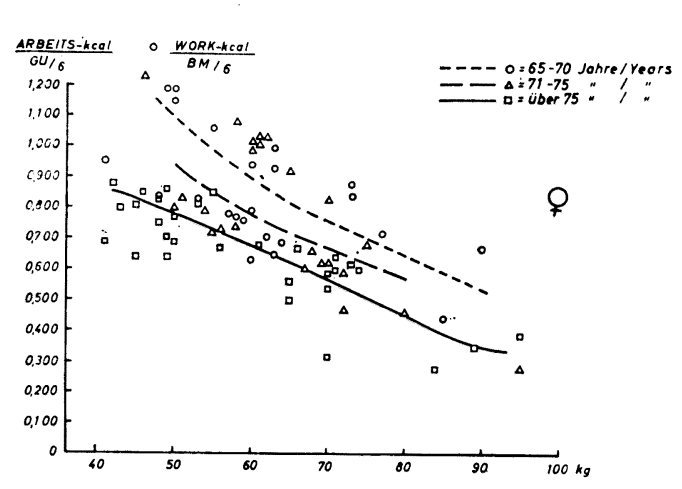

The monotony in the consumption of foodstuffs

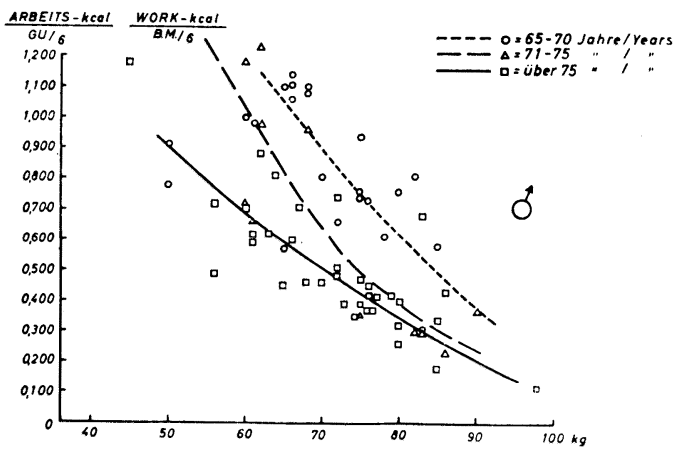

Bibliographie-Literatur-Bibliography

1) Wirths, W. : Nahrungsverbrauch und Energieumsatz in bauerliches Haushaltes. Landwirtschaft -Angewandte Wissenschaft. Heft Nr 112, Lands chaftsverlag GmbH., Hiltrup bei Münster 1962.

2) Lehmann, G. : Praktische Arbeitsphysiologie. Thieme-Verlag, Stuttgart 1953.

3) Kraut, H., Lehmann, G. und Bramsel, H. : Ve rschlag zu einer Ernährungsstatistik auf der Grundlage des Nahrungsbedarfes der einzellnen Berufe, Arbeitsphysiol. Band 10, S. 440-458(1939).

KÖRPERGEWICHT UND ARBEITSUMSATZ IN GU/6

Fig 10 WEIGHT AND WORK METABOLISM IN BM/G

4) Die wünschenswerte Höhe des Nahrungszufuhr. Empfehlungen des Ausschusses für Nahrungsbed arf der Deutschen Gesellschaft für Ernährung

e.V., Frankfurt/Main, erste Mitteilung, Umschauverlag, Frankfurt/Main 1956.

5 ) Ross, W.C. : The aminoacid requirements of adult man, Nutr. Abstr. Rev. Jg. 27,S. 631-647 (1957).

6 Ross, W.C.., Haines, W.J. and Warner, D.T. : The aminoacid requirements of man, Journ. biol. Chem. XIV., Jg. 206, S. 421-430 (1954); XV., Jg. 217, S. 987-995 (1955); XVI., Jg. 217, S. 997-1004 (1955).

7) Wirths, W. : Über den Anteil industriell verarbeiteter Nahrungsmittel an der gegenwärtiges Ernährung in der Bundesrebublik Deutschland, Berichte über Landwirtschaft, Band 40. Heft 4, S.845-856,1962.

8 ) Lang, K.: Biochemie der Ernährung, Steinkopf-Verlag, Darmstadt 1957.

9) Goldsmith, G.A., Miller, O.N., and Unglaub, W.G. : Efficiency of tryptophan as a niacin precursor, Federation Proceedings, Band 15, S. 553 (1956).

10) Horwitt, M. K., Harvey, C. C., Rothwelt, W.S., Cutler. J. I., and Hoffron, D. : Tryptopan-niacin relationships in man, J. Nutrition, Band 60 , Suppl. No. 1 (156).

11) Glatzel, H. : Haben wir genug Vitamine in unserer Kost. Ärzliche Praxis, XII. Jahrg.,Nr.37-44(1960).

12) Recommended Dietary Allowances, Food and Nutrition Board, National Research Council Publication 589. Revised 1958, Washington, D.C., 1958.

（抄訳は次頁に） 
西独農家の耕地面積は，その90\%までが40エーカー以 下である。これら小農における労働と食物掞取とのエネ ルギー収納の関係を知るために，41地区 400 世帯を対象 として, 農慗期の30日間にわたる栄養調査を施行した。

一般に, 耕地面積の少い農家ほど, 栄養攝取には苦労 しているが，西独農家では，イタリーに多発していると いう脚気, ペラグラ, 壊血病などの栄養欠乏性疾患は, 全くみあたらなかった。

調査成績を正確に評価するために, 対象を農 業の種 類, 性, 年令, 体重, 身長によって分類し,さらに必要 栄養量をドイツ栄養協会の勧告と基礎代謝率を考虑して 計算し検討することにした。

その結果, 1 人 1 日当りの平均栄鉴捋取量は表 3 のご とくであるが，攝取食品の種類ととあに地域的にひじょ うに大きな差がみとめられた（表 4 )。これらの数值を 検討してみると, なお一部の農家では, 蛋白質総量およ び動物性蛋白の摄取が不足しているとと，ほとんどの農 家で脂肪摂取量が過剩の傾向があるとと，ミネラルのう ちカルシウムが不足がち, ビタミンのうち $\mathrm{B}_{1}, \mathrm{~B}_{2}, \mathrm{C}$, Aが十分でない農家がかなりあるとと等が指敵された。 さらに個々の主要な栄養素について, 検討してみると次 のごとくであった。

蛋白質 : 全農家の平均摄取量は 1 人 1 日 $92.1 \mathrm{~g}$ で, 基 準量 $(93 \mathrm{~g}$ ) の99\%にあたり，44世帯の脤家が基準量の 80\%に達しないととがわかった。動物性蛋白は平均53.1 $\mathrm{g}$ で基準量 $(42 \mathrm{~g})$ をかなり上まわった。そこで, 蛋白 攝取量が基準量の80\%にみたない農家18戸について，必 須アミノ酸量を分析した結果, Valine, leucine, isoleucine, threonin, phenylalanine, lysin, tryptophane 基準量を超えていたが, methionine の攝取が不十分で あった。

脂肪 : 基準量が99 g であるのに対して, 実さいの摄取 量は, 平均 $144 \mathrm{~g}$ (146\%) で, 全熱量の40\%を占め, 大 附表は原文参照
幅な超過であった。

カルシウム : 掞取量の平均が基準量の $110 \%$ であった が, 基準量以下の農家が340世帯中140世帯むあった。

リン: 労働者においては, 筋代謝上からみてもその十 分な攝取が必要があるが, 攝取量の平均は基準量の 126 \%で, 基準量の80\%以下は14戸であった。

鉄 : 食物中の鉄分のうち吸収されるのは, ごく一部で あるから，かなり多量に摄取する必要があるといわれ る。摂取量の平均は基準量の $150 \%$ で, 不足は 16 世帯 (80\%以下 2 世帯) であった。

ビタミン : 基準量は 4,530 I. U. であるが摂取量の平 均は122\%であった。しかし80\%に達しない世帯が38世 帯もあった。

ビタミン $\mathrm{B}_{1}$ : 摂取量の平均值は $1.9 \mathrm{mg}$ で，ほほ基準 量（99.9\%）であったが，204 世帯が基準量に達しなか った。非脂肪性熱量摄取の問題を考えると，まだ大多数 の世帯では捸取不十分で（表 7)，その是正には食習慣の 改善が必要と考えられた。

ビタミン B : 摂取量の平均は基準量の $123 \%$ 占めた が，基準に達しない世帯が1/4あった。

Niacin: Tryptophane がその Provitamine と考えら れるので，その摂取量む同時に考慮すべきである。考慮 しない成績では，41世帯が不足した。

ビタミンC : その基準量は $75 \mathrm{mg}$ であるが, 摄取量の 平均は126\%で，75世帯が不足であった。

さらに, 年令とカロリ一量, 労作代謝との関係を調査 した結果，（表 8，5),男女とあに75才以上であなお重 労働に従事しなければならないあのがあるととは大きな 問題であった。

以上の調査を通じて, あっとも著明な特色は, 食品消 費の単調さにあり, この点は, 摄取量が基準量に達しな いととよりあ重要な問題であると考えられた。以上の資 料が, 西独小農の経済的および社会的地位についての理 解を深める一助となれば幸である。

（野田） 